\section{Fibrinolytic Activity of Tissue Extracts and of Trypsin}

Macfarlane and Biggs ${ }^{1}$ have reported on fibrinolytic enzymes in extracts of human tissues. The recent isolation of a soluble fibrinolytic activator from washed and dehydrated pig heart tissue ${ }^{2}$ suggested a re-investigation of the fibrinolytic activity of such tissue extracts.

Saline extracts were prepared from the ground tissue from human lung and pig brain. The extracts were very active when estimated by the standard fibrin plate method ${ }^{3}$, where the substrate (bovine fibrin) contains plasminogen. No fibrinolytic effect was observed when the extracts were tested on fibrin plates in which the plasminogen had been destroyed by heating as described by Lassen ${ }^{4}$. However, an effect was obtained when bovine plasminogen was added to the extracts, the size of this effect depending upon the amount of plasminogen applied (see graph).

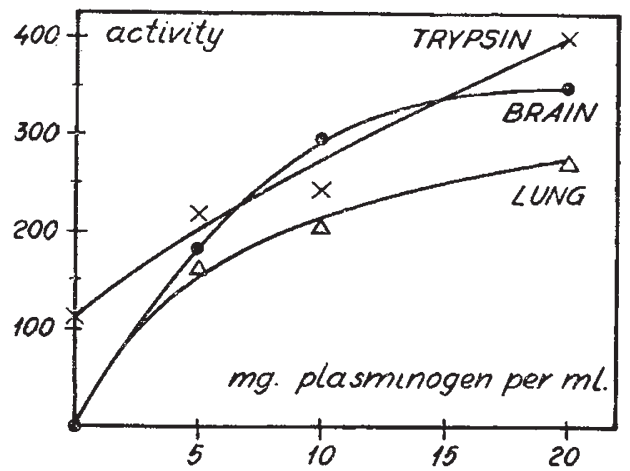

Fibrinolytic effect of pig brain extract, human lung extract and crystalline trypsin on plasminogen-free fibrin when the concentration of bovine plasminogen in the active solutions is varied. Abscissa : Concentration of the plasminogen preparation in the sample. Ordinate : Activity recorded as the diameter product

It is evident that the fibrinolytic agent contained in these extracts is an activator of plasminogen and not a fibrinolytic enzyme proper. It may be recalled that in extracts prepared from heavily disintegrated tissue (Potter homogenizer, Waring blendor) the fibrinolytic activity is caused by an activator present in the small particles ${ }^{5}$.

In similar experiments the effect of plasminogen on the activity of a number of proteolytic enzymes was investigated. An increase in plasminogen concentration had only a slight effect on the activity of chymotrypsin (cryst., Armour), of an Aspergillus protease obtained from Dr. W. (T. Crewther, of a proteinase from $B$. subtilis (obtained from Prof. K. Linderstrøm-Lang, Copenhagen) and of bovine plasmin (prepared by activation with fibrinokinase or spontaneously?). However, when trypsin (cryst., Armour) was added, an enormous increase in activity was produced when the concentration of plasminogen was increased (see graph).

Trypsin, therefore, in addition to its effect as a proteolytic enzyme, appears to act as an activator of plasminogen. Most probably this activation depends upon a partial proteolytic splitting of the plasminogen molecule. This action resembles the known effect of trypsin in blood clotting, by which prothrombin is converted into thrombin.
This investigation has been aided by a grant from the Josiah Macy, jun., Foundation, New York.

TAGE AstruP

TnA STERNDORFF

Biological Institute,

Carlsberg Foundation, Copenhagen. July 4.

${ }^{1}$ Macfarlane, R. G., and Biggs, R., Blood, 3, 1167 (1948).

'Astrup, T., and Stage, A., Nature [170, 929 (1952)].

3 Müllertz, S., Acta Physiol. Scand., 25, 93 (1952). Astrup, T., and

Müllertz, S., Arehiv. Biochem. Biophys., 40, 346 (1952).

"Lassen, M., Acta Physiol. Scand. (in the press).

5 Tagnon, H. J., and Petermann, M. I., Proc. Soc. Exp. Biol. Menl. ro, 359 (1949). T'agnon, II. J., and Palade, (1. E., $J$. Clin. Invest., 29,317 (1950). Lewis, J. 11., and Ferguson, J. H., J. Clin. Invest., $29,1059(1950)$

(crewther, W. G., and Iennox, li. G., Nature, 165, 680 (1950).

Astrup, T., Biochem. J., 50, 5 (1951).

\section{Migration and Gregarious /Estivation in the Bogong Moth, Agrotis infusa}

IN 1834, Bennett ${ }^{1}$ reported immense aggregations of the bogong moth, Agrotis infusa (Boisd.) (Noctuidr, Lep.), in the elefts and small caves of granite outcrops on mountain-tops in southern New South Wales. There the aboriginal tribes congregated to feast upon these moths, which constituted a valuable fat-rich food. Scott ${ }^{2}$ and others confirmed these observations, but no satisfactory explanation for the moth assemblages has been offered.

Aggregations of $A$. infusa have been studied during the past two summers at several sites, between $4,000 \mathrm{ft}$. and 6,000 ft., on the Brindabella Range in the Australian Capital Territory. Moths began to assemble on the mountain tops late in October and the populations reached a maximum before midDecember. In late November, a large unidirectional flight in a southerly direction was observed at a point four miles north of the chief observation site, Mt. Gingera $(6,092 \mathrm{ft}$.$) . There was no major decline in$ populations before the end of March, when all the moths disappeared. In early April, another large unidirectional flight, this time in a northerly direction, was observed near Mt. (Xingera.

Strongly gregarious behaviour was indicated by the layer of moths which covered, in a compact imbricated pattern, large irregular areas of the rock surfaces in the crovices and caves. For about one hour night and morning, just after sunset and before sunrise, a small proportion of the moths became intensely active and many indulged in a milling flight over the summit of the mountain, even when the outside air temperature was $7 \cdot 0^{\circ} \mathrm{C}$. At no time during these periods of activity was copulation or feeding observed. Dissections of a hundred female moths taken from the caves at weekly intervals throughout the summer showed that spermatophores were never present in the bursa copulatrix, where they are normally deposited during copulation. Without exception the ovaries were immature and the fat body well developed. Although sugary food was apparently not sought, water may have been ingested from rock surfaces moistened by rain or dew. In the laboratory, moths taken from the assemblages at Mt. Gingera neither copulated nor laid fertile eggs when fed water alone but did so when fed a sucrose solution. Some 10,000 moths, confined to a small cave on Mt. Gingera by means of wire gauze on January 10 , behaved in a similar 